\title{
Beyond "universal grammar"
}

\author{
Review: Marcello Barbieri, The Organic Codes: \\ The Birth of Semantic Biology. Ancona: Pequod, 2001
}

\section{Noam Chomsky ${ }^{1}$}

\section{Dear Professor Barbieri, ${ }^{2}$}

Just found this book at my office today ${ }^{3}$, in the usual huge stack of mail, books, papers, etc. It looked so intriguing that I started reading it on the way home. Luckily for me, the bus was late, so I had more than the usual amount of time. It is really fascinating. About half way through before the bus stopped, I got back to it later.

Your book is very much along the lines of my own recent work, in some ways. Since the modern subject of the study of language took shape about 50 years ago in what's sometimes called a "biolinguistic" framework, it seemed clear to me that some day we would have to try to go beyond "universal grammar" - the relevant genetic endowment - and try to find out not just what it is but why it is this way, looking for the kinds of factors you mention in discussing cellular epigenesis. I was much intrigued by work of Turing (1952) on morphogenesis, and D'Arcy Thompson's classic work (Thompson 1942). In recent years, enough has been learned so that the questions seem perhaps open to serious inquiry, and what seems to be a sensible research program has taken shape, with I think interesting results. Some of the best work is being done not far where you are (teaching embryology) — in Siena,

${ }^{1}$ Author's address: Noam Chomsky, Department of Linguistics and Philosophy, Massachusetts Institute of Technology, MIT E39-219, 77 Massachusetts Avenue, Cambridge, MA 02139 USA; e-mail: chomsky@mit.edu.

${ }^{2}$ Marcello Barbieri is an Italian developmental biologist from the University of Ferrara, the president and founder (in 1997) of the Italian Association for Theoretical Biology. The Organic Codes is a development and extension of his earlier book, The Semantic Theory of Evolution (1985), which has appeared with René Thom's foreword, and of his several papers (Barbieri 1987, 1997). For another review on M. Barbieri's book see: Kull, K. 2001. Living forms are communicative structures, based on the organic codes. Cybernetics and Human Knowing 8(3). [Editorial footnote.]

${ }^{3}$ March 9, 2001. 


\section{Noam Chomsky}

Milan, Venice, and a few other places. Had the great pleasure of spending a month in Siena about a year ago.

Here are a few comments, based on first quick reading. One issue that seems to me unclear is whether what you call "the strong version" (p. 21) is really a falsifiable hypothesis. You write (p. 21):

[...] the cell theory can be expressed either in weak or in a strong version. The theory can indeed be reduced to a mere description of life when it is formulated by saying that 'all known living organisms are made of cells'. In this case it has no predictive power and no falsifyable consequence.

But there is also a strong version that does represent a true falsifyable generalization of the empirical facts, and therefore a true scientific theory. It is the statement that 'all possible living organisms are made of cells'.

That can be so only if the concept "living organism" is antecedently defined. But it seems to me that the project at this point is to define it. Not an unfamiliar pattern in the history of the sciences.

Anyway, I am really enjoying the book. I have indeed finished it, with much appreciation. It is very stimulating and thought-provoking. Thanks for sending it.

\section{References}

Barbieri, Marcello 1985. The Semantic Theory of Evolution. London: Harwood Academic Publishers.

- 1987. Co-information: A new concept in theoretical biology. Rivista di Biologia 80: 101-126.

- 1997. Biological forms as natural conventions. Rivista di Biologia 90: 485-488.

- 2001. The Organic Codes: The Birth of Semantic Biology. Ancona: Pequod.

Thompson, D'Arcy Wentworth 1942. On Growth and Form. Cambridge: Cambridge University Press.

Turing, Alan 1952. The chemical basis of morphogenesis. Philosophical Transactions of Royal Society London B 237: 37-72. 